\title{
DO TOURISTS WILLING TO PAY FOR THE VALUE OF ENVIRONMENTAL CONSERVATION? A CASE OF ANNAH RAIS LONGHOUSE AND HOT SPRINGS
}
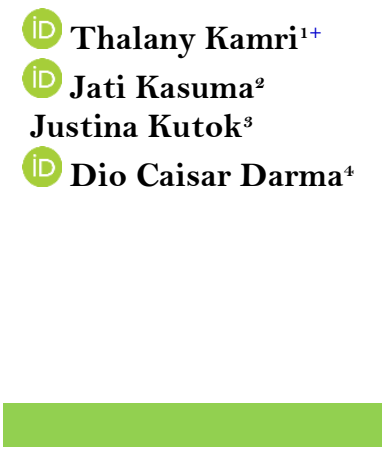

Article History

Received: 5 August 2020 Revised: 7 September 2020 Accepted: 16 September 2020 Published: 9 October 2020

\section{Keywords}

Conservation

Willingness to pay

Environmental

Longhouse

Valuation.

\author{
'Senior Lecturer, Faculty of Business and Management, Universiti Teknologi \\ MARA Sarawak, Jalan Meranek, Malaysia. \\ Email:thalanyk@uitm.edu.my \\ 'Assoc Prof., Faculty of Business and Management, Universiti Teknologi \\ MARA Sarawak, Jalan Meranek, Malaysia. \\ Email: jati@uitm.edu.my \\ ${ }^{3}$ Alumni, Faculty of Business and Management, Universiti Teknologi MARA \\ Sarawak, Jalan Meranek, Malaysia. \\ ${ }^{\text {}}$ Researcher, Depertment of Management, Sekolah Tinggi Ilmu Ekonomi \\ Samarinda, Jalan K. H. Abul Hasan, Indonesia.
}

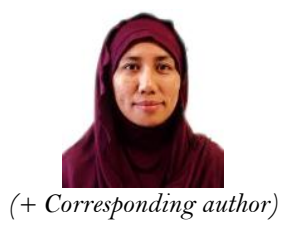

ABSTRACT

There is a need to protect the good nature, environment, and the culture of Bidayuh ethnic in the setting of Annah Rais Longhouse and Hot Springs. In order to manage Annah Rais Longhouse and Hot Springs for long term sustainability, the study on economic valuation is necessary. This is to understand the importance of environmental conservation value. This study seeks to determine visitor's willingness to pay for conservation fees in Annah Rais Longhouse and Hot Springs, at Kota Padawan, Sarawak. The data were obtained from questionnaires handed out to a 330 visitor who visited Annah Rais Longhouse and Hot Springs. The results revealed that the nonMalaysian visitors' average willingness to pay was RM14.12 per visit and the local visitors' average willingness to pay was RM5.49 per visit for environmental conservation. The results of this study can benefit the Sarawak Tourism Board to determine the appropriate addition to the entrance fee at Annah Rais Longhouse and Hot Springs. Hence, encouraging appropriate conservation activities to protect the environment and the culture of Bidayuh ethnic.

Contribution/Originality: This study contributes to existing literature by determining visitor's willingness to pay for conservation fees in Annah Rais Longhouse and Hot Springs, at Kota Padawan, Sarawak.

\section{INTRODUCTION}

The natural environment also plays an important role in tourism industry. It is because the nature-based tourism has become the fastest growing tourism in the past decades or more. Protected areas are recognized as an appliance to conserve biodiversity and preserve ecological processes (Dudley, 2008; Fajriansyah \& Darma, 2017). Thus, protected areas are important for the conservation of natural habitats, species, and genetic diversity. The protection of the natural environment is a basic part of tourism development. The total forested area of the Malaysia in 2011 is estimated as 17.98 million hectares (MTIB, 2012). Nevertheless, most are still not proclaimed as protected area. There are 14 protected areas in Sarawak. However, Hot Springs is not included in the list. The protected areas in Sarawak have attracted increase in the numbers of local and foreigner visitors, helping to develop tourism as a source of foreign exchange earnings. The Hot Springs has potential to become a tourism destination that can contribute to Malaysian Economy. 
In Sarawak, it has the oldest of Bidayuh's longhouse known as Annah Rais Longhouse which located in Kota Padawan at about $70 \mathrm{~km}$ away from Kuching City. The Annah Rais Longhouse is at the foothill of Borneo Highlands near the mountains marking the border to Kalimantan. It is an old Annah Rais Longhouse and the houses over 80 families. The villager still practices the way of longhouse's living. The villagers carry out daily activities such as plant paddy, pepper, rubber and other for the purpose of self-sufficiency. Annah Rais Longhouse has become a homestay and it is the only one of the remaining Bidayuh longhouses in Kuching where the visitors can stay and experience the way Bidayuh living. The total of visitors that visited to Annah Rais Longhouse in 2016 is 12,870. All the visitors who visit or stay at Annah Rais Longhouse will be greet with their traditional drink namely 'Tuak' or known as rice wine. This traditional drink is a type of alcohol which is made from distilled rice.

The unique of Annah Rais Longhouse is the Head House which is that house contains a lot of enemy head skulls. The Bidayuh Community will organize outdoor activities for visitors who stay at Annah Rais Longhouse. The visitors will go for jungle trekking in the tropical rainforest, hunting with blowgun, bamboo rafting, and barbeque lunch at river or waterfall, soaking in the natural Hot Springs, swimming at the untouched natural 3-tier waterfall, and rice harvesting. While Annah Rais Longhouse indoor activities, the visitors will learn how to cook Bamboo rice and Bamboo chicken, blowgun skill competition, watch Bidayuh traditional cultural dance performance, will learn how to play Bidayuh musical instruments, learn how to weaving basket and crafting, and exploring the Annah Rais Longhouse. Currently the longhouse's committee charged the entrance fee to visitors, whereby the fund that collected will be used for maintenance and to preserve the Bidayuh's cultures. The entrance fee for Annah Rais Longhouse is RM8 for adult and RM5 for children.

At Annah Rais also have a natural jungle spa called Hot Springs which is about 10 minutes from Annah Rais Longhouse. It is located in the river with running crystal-clear mountain water, and colourful small pebble stones on the riverbeds. In the past, the early settler in Annah Rais longhouse has kept secret about hot springs for 250 years, but now it is open to the public. In Bidayuh beliefs, it is a holy place to seek blessings and cures for sickness. Annah Rais Hot Springs is protected from pollution. The place was quiet and very peaceful. It has two different rivers, which is cold water and hot water. The hot water is a natural feature caused by underground water being heated by geothermal forces brought to the surface. In 2016, the total of visitors that visited to Hot Springs is 6,668. The entrance for adult is RM 5 per person and RM3 for children.

\subsection{Research Problem and Research Objectives}

The role of nature conservation is to protect a natural resource which is so important to nature-based tourism and recreation destination. However, establishing and managing protected areas is an expensive business that requires funds to achieve a balance between conservation and recreation or tourism parks. As stated by Eagles, McCool, and Haynes (2002) tourism based on protected areas can be a primary factor in supporting the conservation of the natural and cultural heritage. Since Annah Rais Longhouse and Hot Springs is far from city and not well known by local and international visitors, the place is not well conserved. Therefore, it is important to protect the Annah Rais Longhouse and the natural resources of Hot Springs. Hence, the awareness to protect can be initiated through the visitor's willingness to pay for conservation of Annah Rais Longhouse to maintain the original structure and natural resources of Hot Springs. The aim of this study is to determine how much the visitor is willing to pay for conservation the Annah Rais Longhouse and natural resources of Hot Springs.

The research is to determine how much the visitor is willing to pay for conservation the Annah Rais Longhouse and natural resources of Hot Springs. There are a few research objectives that need to be study. Thus, this study was undertaken to determine how much the local and foreigner visitors' willing to pay for entry fees at Annah Rais Longhouse and Hot Springs. The objective was to derive quantitative data on their willingness to pay for entry and eagerness to support for nature conservation. The Annah Rais Longhouse and Hot Springs potentially attract either local or foreigner visitors to visit this place. This place is ideal for recreation as well as 
homestay. Additionally, the Annah Rais Longhouse and Hot Springs also perform tourism functions. The Annah Rais Longhouse and Hot Springs have beautiful natural assets such as hot springs and a popular tourist destination.

\section{LITERATURE REVIEW}

Malaysia has many unique features and attractions that can be developed as a world-famous tourist destination. The main asset of the nation apart from the beauty of nature and the historical place is its cultural diversity. In the context of culture-based tourism, the country has its own strengths due to the unique and potentially diverse cultures being developed as a country tourism product. Tourism plays an important role for Malaysia where it can contribute to Malaysia economy through foreign exchange earnings.

Generally, tourism is the largest economic sector in the world which also involves several related sectors such as food, transportation, place, location attractions and other services. This sector is one of the major contributors to the country's economic development. Tourist developments are caused by human movements to find something they have not yet known, to explore new areas, to look for mood changes or to get new trips alongside improving the quality of life of the world's population. This situation shows that tourism is a thriving sector in the world including Malaysia. Tourism also is a social, cultural and financial phenomenon that includes the movements of people to national locations or place outside the ordinary environment for personal, business or professional needs. The establishment of tourism industry can attract a lot of people where most of them from government servant and private sector which have potential to contribute to Malaysia economy and sociocultural. As claimed by Fawaz and Rahnama (2014) tourists can help in increase the sales, profits, tax revenue, and therefore leads to general revenue growth in the host country.

In addition, tourism can bring in a lot of foreign exchange and offer more occupation to people. According to Badaruddin and Shida (2008) tourism can increase a nation's profit as well as creating employment chance as many as $10 \%$ from the world's occupation account and as many as $11 \%$ from the Gross Domestic Product (GDP).In other research stated by Mansfeld and Winckler (2008) they also said that tourism has potential as a contributor through tourism industry in economic sector based on many of nations that survive and improve the national economy. The tourism industry impacts positively on economy as well as increasing in foreign exchange in the country which would help promote new investment in the country and increase job opportunities (Darma, Maria, Kasuma, \& Lestari, 2020).

Besides of tourism industry, protected areas also have an important role in order to improve Malaysia's economy. Protected areas are considered as the basic of biodiversity conservation in worldwide. The motive of establishing protected areas is to protection of ecosystems, the preservation of ecological processes and also conservation of biodiversity (Baral, Stern, \& Bhattarai, 2008). According to Eagles et al. (2002) they claimed that protected areas are established primarily to preserve some type of biophysical process or condition such as a wildlife population, habitat, natural landscape, or cultural heritage such as a community's cultural tradition.

In Malaysia, there are Sarawak is one of the states that is a tourist attraction due to its rich diversity of cultures. The diversity of ethnic cultures in Sarawak also has become one of the major factors for tourists to make Sarawak a tourist destination. Apart from the Malays, Melanau, Iban and Bidayuh, there are other small groups such as Kayan, Kenyah, LunBawang, Tagal, Kelabit, Penan, Kajang, Bisaya, Tabun, Saban, and Bukitan. Each group of these societies has a difference in each other. They are small society of the Sarawak population.

One of this place at Sarawak which is at rural area that has potential to become a tourism destination that can contribute to Malaysian Economy which is Annah Rais Longhouse and Hot Springs located at Kota Padawan, Sarawak. Rural tourism is a rapidly growing service industry in our country. This scenario makes Malaysia the third most widely accepted Asian East Asian tourist destination after China and Hong Kong. The rural tourism can provide travellers with the experience of appreciating the life of the village and experiencing culture and customs. According to Inskeep (1991) rural tourism is not just farm-based tourism but including special importance and 
ecotourism, walking, climbing and riding, doing adventure, sports and health tourism, hunting and fishing, tourism education, tourism and tourism heritage some ethnic tourism areas.

The state of Sarawak is a state inhabited by several ethnic groups who have different customs and languages and ways of life. Even their place of residence also seems to have been a division and separation. At Annah Rais Longhouse and Hot Springs areas are one of the areas which are dominated by the Bidayuh. The Bidayuh community is a native ethnic group inhabits the south-western part of Borneo and in Sarawak is only in the first part, settling ahead of other ethnic natives. The Bidayuh are ethnic in Sarawak. The largest population is in the first part, namely Kuching. Bidayuh are found in Bau, Lundu, Penrissen, Padawan and Serian areas. 'Bidayuh' or in the language of the race itself means 'land people'. The 'Bi' means Dayak or people, while 'Dayuh' means land. In addition to being known as 'Bidayuh', this tribe is also known as 'Land Dayaks'. At different areas will be different dialects. The dialectic tribes from the Serian or Samarahan district will identify themselves as Dayak Bibir orBisadong by calling themselves as Bibingan, Bitapuh, Bitaup, Bitutoi and so on when interacting with fellow dialects as well as ethnic Bidayuh dialects in Penrissen, Padawan and Kuching areas. They will identify themselves as Biaatah, Bipuruh, Biannah and Bibengoh. While in the Bau and Lundu districts they call themselves the Bijagoi, Bisalui, Biselako, Bilara, Bipueh and so forth which refer to the boundary of the district or the place of origin.

In Annah Rais, the group of Bidayuh who live here is Biannah. The meaning of word 'Biannah' is people of Annah Rais. The word "Biannah" is actually derived from the word Bidayuh 'bi' which means the people and 'Annah' is the name of the village (Rais) and the name of the river. Therefore, "Biannah" means "Annah Rais People". At Annah Rais, there is a 12-hectare longhouse belonging to the Bidayuh community that still exists in this country. The longhouse which still retains some of its original features despite the rapid economic and physical development in the vicinity, still maintains the harmony of the Bidayuh community. Annah Rais longhouse was built in 1818 and starts with three houses and now it has expanded to 146 houses with 1,228 people registered. Because the Annah Rais longhouse is no longer able to accommodate the growing population, many new generations build their homes around the longhouse. This longhouse is about 200 years old. Other than that, people at Annah Rais Longhouse have kept secret about Hot Springs for 250 years but know this place is open to the public. Since this place has a good nature and environment, it is important to protect this place through conservation program or impose conservation fee to maintain the original structure of Annah Rais Longhouse and natural resources of Hot Spring.

In numerous nations of the world, especially developing nation, protected areas used to be the only natural places where the natural resources could be found and nowhere else in the world (Pettorelli et al., 2012) and a protected area were charges an entrance fee to generate a fund to meet its management cost. The majority of protected areas throughout the world, however, majority are not financially self-sufficient and consequently are unable to meet the conservation objectives (IUCN, 2005). It means an entrance fee is not enough to fulfil the conservation objectives. Thus, the 'Conservation Fee' also important in achieving the conservation objectives.

To estimate the value or a person's willingness to pay, the contingent valuation is a suitable method for estimating the value that a person places on a good. The contingent valuation method is based on the concepts of the willingness to pay a certain amount in order for the individual to maximize his or her utility or willingness to accept compensation so as to improve his utility as a result of damage, or absence of the public good (Adamu, Yacob, Radam, \& Hashim, 2015).The first introducer of contingent valuation method is Ciriacy and Wantrup in 1947 where they it used to estimating the side effects of soil erosion (Venkatachalam, 2004). The attention of contingent valuation method studies has in the recent past shifted from valuation of the environmental damage to the valuation of environmental protection. It is generally used as an effective policy tool in protected area management and biodiversity conservation (Baral et al., 2008).

In economics, willingness to pay is the base aggregate of cash that individual will acknowledge to leave or to carry on something negative. As defined by Pearce and Turner (1990) the willingness to pay is a tool that used to 
measure of the direct economic use of nature. In previous literature review, willingness to pay method has been used to estimate the value of non-market goods (Reynisdottir, Song, \& Agrusa, 2008) and various experience of willingness to pay have been recognized. According to Bhandari and Heshmati (2010) there are some sociodemographic and other variables found to be important determinants of willingness to pay such as the past disbursement history, period of stay, visitor satisfaction, and attitudes toward the environment. Among the demographic variables age is an important determinant of holiday behavior of a tourist and their choice of tourist spots (Cottrell, 2003; Weaver, McCleary, Lepisto, \& Damonte, 1994).

The most variable that influence is age where an older people tend to be particularly attracted to the outdoor activities. An older people are tending to be more attracted in the kinds of experience offered by protected areas, have more disposable income, and are thus more willing to pay for higher levels of interpretation, guiding and other services (Eagles et al., 2002). As found by Baral et al. (2008) age is most always positively related to the willingness to pay for conservation. Lastly, as found by previous studies, the education also influenced determinant of willingness to pay (Baral et al., 2008). The visitors with higher education level can increase the demand for outdoor recreation activities, and lead to changes in the patterns of recreation and tourism as found by Eagles et al. (2002).

\section{METHODOLOGY}

Respondent has been used by researchers for many years the common term for an individual who takes part in a market research project. The questionnaire will distribute to 330 visitors which is Malaysian and non-Malaysian at Annah Rais Longhouse and Hot Springs. A structured questionnaire will be developed to get information on the willingness to pay for the conservation value at Annah Rais Longhouse and Hot Springs in Sarawak. The questionnaire is divided into four sections. The first section (Section A), measure the frequency of respondents' visits to Annah Rais Longhouse and Hot Springs either for the first time or more than one time. The second section (Section B), measure the reason of respondents visit Annah Rais Longhouse and Annah Rais Hot Springs. This section used 5-point Likert scaled to represent whether they agreed or disagreed with each statement. This section has 20 reason of visit for respondents to rate. The third section (Section C), measuring the visitors' willingness to pay for the conservation value. The respondents has to state their answer whether they agreed or disagreed for conservation fee. The respondents also have to state what maximum price if they agreed, the minimum price if they disagreed, and their feedback and suggestions. The fifth section (Section D), respondent ask to give their personal information. The respondent must answer the question covering gender, age, nationality, education level, monthly income, and occupation.

\section{FINDING AND DISCUSSION}

\subsection{Visitors Demographic Profile}

In this survey, visitors' demographic had been asked in Section D which included gender, age, nationality, education level, monthly income, and occupation. Table 1 below shows the summary of visitors' profile.

\subsection{Characteristics of Visits}

Based on Table 2, the visitors that come for the first time to Annah Rais Longhouse and Annah Rais Hot Springs is about $60.5 \%$. While the rest is $39.5 \%$ who visited many times, which is $17.0 \%$ visited more than 3 times, followed by $14.3 \%$ for 2 times, and $8.2 \%$ for 3 times. Majority of visitors with total percent $76.9 \%$ are agreed that conservation fee should be charge. Most of visitors with total percentage $48.3 \%$ are complaints towards the services, cleanliness, and facilities that provided by Annah Rais Longhouse and Hot Springs, followed by $17.0 \%$ of visitors suggested that Annah Rais Longhouse and Hot Springs should add more activities, 12.9\% of visitors suggested should provide adequate parking space, $6.8 \%$ visitors suggested should provide more place for BBQ and variety of 
foods, $6.1 \%$ of visitors suggested the size of Hot Springs pool should be expand, and $2.0 \%$ of visitors suggested should provide more available room at Annah Rais Longhouse.

Table-1. Summary of visitor's profiles.

\begin{tabular}{|c|c|c|}
\hline Characteristics & $\mathbf{n}$ & Percentage (\%) \\
\hline \multicolumn{3}{|l|}{ Gender } \\
\hline Male & 51 & 34.7 \\
\hline Female & 96 & 65.3 \\
\hline \multicolumn{3}{|l|}{ Age } \\
\hline $18-20$ years & 6 & 4.1 \\
\hline 21-30 years & 98 & 66.7 \\
\hline 31-40 years & 28 & 19 \\
\hline $41-50$ years & 8 & 5.4 \\
\hline 51 and above & 7 & 4.8 \\
\hline \multicolumn{3}{|l|}{ Nationality } \\
\hline Malaysian & 134 & 91.2 \\
\hline Non Malaysian & 13 & 8.8 \\
\hline \multicolumn{3}{|l|}{ Education Level } \\
\hline Doctorate & 2 & 1.4 \\
\hline Master's degree & 10 & 6.8 \\
\hline Bachelor's degree & 77 & 52.4 \\
\hline Diploma & 44 & 29.9 \\
\hline SPM & 14 & 9.5 \\
\hline \multicolumn{3}{|l|}{ Monthly Income } \\
\hline Below RM1000 & 77 & 52.4 \\
\hline RM1001-1500 & 10 & 6.8 \\
\hline RM1501-2000 & 10 & 6.8 \\
\hline RM2001-2500 & 16 & 10.9 \\
\hline RM2501-3000 & 10 & 6.8 \\
\hline RM3001-3500 & 3 & 2 \\
\hline RM3501-4000 & 4 & 2.7 \\
\hline RM4001 and above & 17 & 11.6 \\
\hline \multicolumn{3}{|l|}{ Occupation } \\
\hline Government servant & 25 & 17 \\
\hline Private employee & 44 & 29.9 \\
\hline Retiree & 4 & 2.7 \\
\hline Student & 74 & 50.3 \\
\hline
\end{tabular}

Table-2. Summary of Visitor's characteristics.

\begin{tabular}{|c|c|c|}
\hline Characteristics & $\mathbf{n}$ & Percentage (\%) \\
\hline \multicolumn{3}{|l|}{ First time visit } \\
\hline Yes & 89 & 60.5 \\
\hline No & 58 & 39.5 \\
\hline \multicolumn{3}{|l|}{ If 'No', how many times visited this place } \\
\hline 2 times & 21 & 14.3 \\
\hline 3 times & 12 & 8.2 \\
\hline More than 3 times & 25 & 17 \\
\hline \multicolumn{3}{|l|}{ Conservation should be charge } \\
\hline Yes & 113 & 76.9 \\
\hline No & 34 & 23.1 \\
\hline \multicolumn{3}{|l|}{ Suggestion by visitors } \\
\hline Improve the services, cleanliness, and facilities & 71 & 48.3 \\
\hline Expand the pool size & 9 & 6.1 \\
\hline Provide adequate parking & 19 & 12.9 \\
\hline Add more available room at Annah Rais Longhouse & 3 & 2 \\
\hline Add more activities at Annah Rais Longhouse and Hot Springs & 25 & 17 \\
\hline Provide more place for BBQ & 10 & 6.8 \\
\hline Provide a variety of foods & 10 & 6.8 \\
\hline
\end{tabular}




\subsection{Exploratory Factor Analysis}

Factor analysis was conducted on Section B which is factors that influence visitors to visit Annah Rais Longhouse and Annah Rais Hot Springs. The Kaiser-Meyer-Olkin's (KMO) and Bartlett's Test was used to test the appropriateness of Factor Analysis. Based on Table 3, the result of the factor analysis also indicated that the measure for Kaiser-Meyer-Olkin's (KMO) measure of sampling adequacy (MSA) was 0.804 (greater than 0.50). These tests indicated that there is adequate number of significant inter-correlation required of variable. The approximate of Chi-square is 1602.858 with 190 degrees of freedom, which is significant at <0.05 level of significance. Hence, Factor Analysis is considered as an appropriate technique for further analysis of the data.

Table-3. KMO and Bartlett's Test

\begin{tabular}{l|l|c}
\hline Kaiser-Meyer-Olkin Measure of Sampling Adequacy. & .804 \\
\hline \multirow{3}{*}{ Bartlett's Test of Sphericity } & Approx. Chi-Square & 1602.858 \\
\cline { 2 - 3 } & df & 190 \\
\cline { 2 - 3 } & Sig. & .000 \\
\hline
\end{tabular}

Table 4 shows the correlation of the variable with each of the extracted factors. The values that have been highlighted was show the maximum value in each of the rows to group the 10 variables into 3 core factors. As suggested by Nunnally, Knott, Duchnowski, and Parker (1967) that the reliability of 0.50 to 0.60 is sufficient, even a coefficient more than 0.7 is necessary (Hair, Black, Babin, Anderson, \& Tatham, 1998). For this study, the suitable coefficient alpha is more than 0.60 .

Component Matrix ${ }^{\mathrm{a}}$

Table-4. Factor loading In the Rotated Component Matrix Visitor's reason to visit.

\begin{tabular}{|c|c|c|c|c|c|c|}
\hline & \multicolumn{6}{|c|}{ Component } \\
\hline & 1 & 2 & 3 & 4 & 5 & 6 \\
\hline To challenge my skills and abilities & .675 & & & & & \\
\hline To develop my skills & .605 & & & & & \\
\hline To be in charge of a situation & .704 & & & & & \\
\hline To feel independent & .645 & & & & & \\
\hline To feel free from society's restrictions & .587 & & & & & \\
\hline To challenge nature & .715 & & & & & \\
\hline To be alone & .501 & & & & .443 & \\
\hline To feel close to nature & .551 & & & -.458 & & \\
\hline To observe the beauty of nature & .537 & .440 & & & & \\
\hline To obtain a feeling of harmony with nature & .579 & .458 & & -.407 & & \\
\hline To find quiet places & .525 & & & & .418 & \\
\hline To enjoy the sights, sounds, and smells of nature & .615 & .440 & & & & \\
\hline To be with my friends or family & & .643 & & .481 & & \\
\hline To strengthen relationship with friends or family & & .667 & & .496 & & \\
\hline To do things with other people & .494 & & & .421 & & -.558 \\
\hline To be with people with similar interests & .536 & & & & & -.555 \\
\hline To escape from the pressure of work & .501 & & .616 & & & \\
\hline To relieve my tensions & .558 & & .579 & & & \\
\hline To get away from my everyday routine & .497 & & .664 & & & \\
\hline To be away from other people & .445 & & & & & \\
\hline
\end{tabular}

\subsection{Reliability Test}

Reliability test was assessed by employing Cronbach Alpha. Cronbach Alpha allows us to measure the reliability of different variables. According to Nunnally et al. (1967) in the estimation, a coefficient more than or equal to 0.7 is considered acceptable and a good indication of reliability. Cronbach Alpha applied to each tested variable of reasons of visiting Annah Rais Longhouse and Hot Springs such as more appreciation to nature, spend quality time with people, and to enjoy vacation. In this study, Cronbach's alpha was used to test the reliability. 
Based on Table 5, the overall Cronbach's alpha for all variable that influence the visitor to visit Annah Rais Longhouse and Hot Springs is 0.803.

Table-5. Reliability test.

\begin{tabular}{|c|c|c|}
\hline Name of Construct & Number of items & Coefficient Alpha (0.803) \\
\hline More appreciation to nature & \multirow[t]{7}{*}{6} & \multirow[t]{7}{*}{0.870} \\
\hline To challenge my skills and abilities & & \\
\hline To develop my skills & & \\
\hline To be in charge of a situation & & \\
\hline To feel independent & & \\
\hline To challenge nature & & \\
\hline To enjoy the sights, sounds, and smells of nature & & \\
\hline Spend quality time with people & \multirow[t]{3}{*}{2} & \multirow[t]{3}{*}{0.895} \\
\hline To be with my friends or family & & \\
\hline To strengthen relationship with friends or family & & \\
\hline To enjoy vacation & \multirow[t]{3}{*}{2} & \multirow[t]{3}{*}{0.771} \\
\hline To escape from the pressure of work & & \\
\hline To get away from my everyday routine & & \\
\hline
\end{tabular}

\section{Research Objective 1: To identify the factors that influence visitors to visit Annah Rais Longhouse and Hot Springs}

As a result of that, the factor analysis has thus identified 3 core factors that influence visitors to visit Annah Rais Longhouse and Hot Springs with total variance of 53.952 percent. They can be categorized as more appreciating to nature, spend quality time with people, and to enjoy vacation as shown in Table 6 below. All the items in these three factors were found have high factor loading of more than 0.6. The loading factors for the three new components range from 0.605 to 0.715 . While the communalities were ranging from 0.608 to 0.887 .

Table-6. Factor analysis on reason to visit.

\begin{tabular}{|c|c|c|c|}
\hline Factor & Variables Included & Loading & Communalities \\
\hline $\begin{array}{l}\text { More } \\
\text { appreciation to } \\
\text { nature }\end{array}$ & $\begin{array}{l}\text { - } \\
\text { - } \\
\text { - } \\
\text { - To de challenge my skills and abilities } \\
\text { - } \\
\text { - } \\
\text { - To feel independent } \\
\text { To challenge nature } \\
\text { To enjoy the sights, sounds, and smells of nature }\end{array}$ & $\begin{array}{l}0.675 \\
0.605 \\
0.704 \\
0.645 \\
0.715 \\
0.615\end{array}$ & $\begin{array}{l}0.846 \\
0.820 \\
0.785 \\
0.713 \\
0.608 \\
0.705\end{array}$ \\
\hline $\begin{array}{l}\text { Spend quality } \\
\text { time with people }\end{array}$ & $\begin{array}{l}\text { - To be with my friends or family } \\
\text { - To strengthen relationship with friends or } \\
\text { family }\end{array}$ & $\begin{array}{l}0.643 \\
0.667\end{array}$ & $\begin{array}{l}0.862 \\
0.887\end{array}$ \\
\hline $\begin{array}{ll}\text { To } & \text { enjoy } \\
\text { vacation }\end{array}$ & $\begin{array}{l}\text { - To escape from the pressure of work } \\
\text { - } \quad \text { To get away from my everyday routine }\end{array}$ & $\begin{array}{l}0.616 \\
0.664\end{array}$ & $\begin{array}{l}0.701 \\
0.813\end{array}$ \\
\hline
\end{tabular}

\section{i. $\quad$ Factor 1 - More Appreciation to Nature}

This first factor characterizes as more appreciation to nature. This factor explains $30.43 \%$ of the variability that influence visitors to visit Annah Rais Longhouse and Annah Rais Hot Springs.

\section{ii. Factor 2 - Spend Quality Time with People}

This second factor characterizes as spend quality time with people. This factor explains $12.95 \%$ of the variability that influence visitors to visit Annah Rais Longhouse and Annah Rais Hot Springs.

\section{iii. Factor 3 - To Enjoy Vacation}

This third factor characterizes as to enjoy vacation. This factor explains $10.57 \%$ of the variability that influence visitors to visit Annah Rais Longhouse and Annah Rais Hot Springs.

Research Objective 2: To identify the price that visitors are willing to pay for conservation of AnnahRais Longhouse and Hot Springs. 
Overall, all the visitors stated out their willingness to pay for conservation fee in different price. Besides from entrance fee, the conservation fee should be charged for maintenance, to preserve the Bidayuh's cultures, and to protect nature. It is needed for people to be concern about the protection of natural resources. In Table 6, it shows the visitors' mean willingness to pay for conservation fee was RM6.25. The finding also revealed that nonMalaysian were willing to pay RM14.12 which is higher than Malaysian at RM5.49 as shown in Table 7.

Table-7. Visitors' Willingness to Pay.

\begin{tabular}{c|c|c}
\hline Respondents & Conservation fee (RM) & n \\
\hline Visitors & 6.25 & 147 \\
\hline Malaysian & 5.49 & 134 \\
\hline Non-Malaysian & 14.12 & 13 \\
\hline
\end{tabular}

Research Objective 3: To identify the value of conservation for Annah Rais Longhouse and Hot Springs.

Table-8. Estimated additional revenue (RM).

\begin{tabular}{c|c}
\hline Respondents & Conservation fee (RM) \\
\hline 2016 & $122,112.50$ \\
\hline Visitors & $65,605.50$ \\
\hline Malaysian & $107,142.56$ \\
\hline Non-Malaysian & $158,937.50$ \\
\hline 2017 & $80,313,21$ \\
\hline Visitors & $152,510.10$ \\
\hline Malaysian &
\end{tabular}

From these values of visitors' willingness to pay for conservation of Annah Rais Longhouse and Annah Rais Hot Springs, the extra net benefit of the place can be computed as shown in Table 8. The estimated additional revenue from conservation fee is the additional benefit that Annah Rais Longhouse and AnnahRais Hot Springs would gain besides the current entrance fee charges. The estimated number of visitors that visited to Annah Rais Longhouse and Hot Springs for 2016 is 19,538 visitors. The estimated number of Malaysian visitors in 2017 is 11,950 and a non-Malaysian visitor is 7,588. While the total number that expected for 2017 is 25,430 visitors. The expected number of Malaysian visitors who visited in 2017 is 14,629 and while non-Malaysian visitor is 10,801. The result in Table 8 show the Annah Rais Longhouse and Hot Springs can gain revenue through non-Malaysian visitors since they are willing to pay higher fee which is RM14.12 compared to Malaysian visitors with amount RM5.49.

\section{CONCLUSION AND RECOMMENDATION}

The main objective of this study is to determine the visitor's willingness to pay for conservation of Annah Rais Longhouse and Hot Springs. The results of this study can benefit the Tourism Board of Sarawak to determine the appropriate entrance fee at Annah Rais Longhouse and Hot Springs and to taking adequate conservation activities to protect the environment and also the cultural of Bidayuh.

The visitors were asked about their willingness to pay more than current fees for a better conservation practice. This study found evidence that both Malaysian visitors and non-Malaysian visitors play an important role in contributing for the purpose of Annah Rais Longhouse and Hot Springs. Majority of the visitors are ready to pay additional fees for a better conservation practices in Annah Rais Longhouse and Hot Springs. The mean of nonMalaysian's willingness to pay per visit was higher compared to Malaysian visitors. Thereby, the results of mean found that non-Malaysian is more concern on the conservation of Annah Rais Longhouse and Hot Springs compared to the Malaysian visitors. The Tourism Board of Malaysia should increase the level of awareness among visitor especially Malaysian visitors. The awareness campaign, mass media propagation, distribution of brochures, 
explaining the importance of the conservation of natural resources should be made to Malaysian visitors as well as Non-Malaysian visitors. When visitors have knowledge about conservation programme, it can cause visitors to feel pay extra money for conservation of Annah Rais Longhouse and Hot Springs. The increasing aggregated benefit could help Bidayuh Community or Tourism Board of Sarawak to solve the arising various problems or issues of Annah Rais Longhouse and Hot Springs such as lack of financial constraint to maintain the activities at these two places. Besides that, when the place is conserved, it can help our young or future generation enjoy the beauty of nature and get to know Bidayuh cultural. Therefore, it is important to impose conservation fee in order to main tain the original structure of Annah Rais Longhouse and natural resources of Hot Spring.

After completing this research, there are some recommendations that can be done by future research. This study was conducted at Annah Rais Longhouse and Hot Springs. The researcher would like to suggest the future researcher should enlarge the sample size of the respondents. In order to set a larger population, the sample must draw from different races, age, and income should be taken into consideration. Besides that, since this research area are far from Kuching City, the researcher suggests future researcher to stay at study area because it might help future researcher to get response easy to collect data from their target respondents.

Funding: This study received no specific financial support.

Competing Interests: The authors declare that they have no competing interests.

Acknowledgement: All authors contributed equally to the conception and design of the study.

\section{REFERENCES}

Adamu, A., Yacob, M. R., Radam, A., \& Hashim, R. (2015). Factors determining visitors' willingness to pay for conservation in Yankari game reserve, Bauchi, Nigeria. International Journal of Economics and Management, 9, 95-1 14.

Badaruddin, M., \& Shida, I. O. (2008). The positioning of Malaysian tourism destinations: An exploratory approach. Paper presented at the Proceedings of National Symposium on Tourism Research, Penang, Malaysia, 26 July 2008. Designing Tourism Research for Practical Applications. Social Transformation Platform.

Baral, N., Stern, M. J., \& Bhattarai, R. (2008). Contingent valuation of eco-tourism in Annapurna conservation area, Nepal: Implications for sustainable park financeandlocal development. Ecological Economics, 66(2-3), 218-227. Available at: 10.1016/j.ecolecon.2008.02.004.

Bhandari, A. K., \& Heshmati, A. (2010). Willingness to pay for biodiversity conservation. Journal of Travel and Tourism Marketing, 27(6), 612-623. Available at: 10.1080/10548408.2010.507156.

Cottrell, S. P. (2003). Influence of socio demographics and environmental attitudes on general responsible environmental behaviour among recreational boaters. Environmental Behaviour, 35(3), 347-375. Available at: $10.1177 / 0013916503035003003$.

Darma, D. C., Maria, S., Kasuma, J., \& Lestari, D. (2020). Factors involved in the number of tourist visits in the Muara Badak, Indonesia. Religación: Revista De Ciencias Sociales Y Humanidades, 5(24), 142-151. Available at: 10.46652/rgn.v5i24.623.

Dudley, N. (2008). Guidelines for applying protected area management categories. Gland, Switzerland: IUCN.

Eagles, P. F., McCool, S. F., \& Haynes, C. D. (2002). Sustainable tourism in protected areas: Guidelines for planning and management. Huntingdon Road, Cambridge: World Conservation Union.

Fajriansyah, F., \& Darma, D. C. (2017). Management of marine potential based on integrated coastal zone management (ICZM) in Kasai Village, Derawan archipelago. Proceedings of the National Seminar on Management and Business Economics, 1(5), 134-142.

Fawaz, F., \& Rahnama, M. (2014). An empirical refinement of the relationship between tourism and economic growth. Anatolia: An International Journal of Tourism and Hospitality Research, 25(3), 1-14. Available at: 10.1080/13032917.2013.876434.

Hair, J. F., Black, W. C., Babin, B. J., Anderson, R. E., \& Tatham, R. L. (1998). Multivariate data analysis (Vol. 5, pp. 207-219). Upper Saddle River, NJ: Prentice Hall.

Inskeep, E. (1991). Tourism planning: An integrated and sustainable development approach: Van Nostrand Reinhold. 
IUCN. (2005). Benefits beyond boundaries: Proceedings of the Vth IUCN world parks congress. The world conservation union. Gland: Switzerland and Cambridge, UK.

Mansfeld, Y., \& Winckler, O. (2008). The role of the tourism industry in transforming a rentier to a long-term viable economy: The case of Bahrain. Current Issues in Tourism, 11(3), 237-267. Available at: https://doi.org/10.2167/cit337.0.

MTIB, M. T. S. (2012). Statistics 2009-2011. Kuala Lumpur: Malaysian Timber Industry Board.

Nunnally, J. C., Knott, P. D., Duchnowski, A., \& Parker, R. (1967). Pupillary response as a general measure of activation. Perception \& Psychophysics, 2(4), 149-155. Available at: https://doi.org/10.3758/bfo3210310.

Pearce, D. W., \& Turner, R. K. (1990). Economics of natural resources and the environment (pp. 378). London: Harvester Wheatsleaf.

Pettorelli, N., Chauvenet, A. L. M., Duffy, J. P., Cornforth, W. A., Meillere, A., \& Baillie, J. E. M. (2012). Tracking the effect of climate change on ecosystem functioning using protected areas: Africa as a case study. Ecological Indicators, 20, 269276. Available at: https://doi.org/10.1016/j.ecolind.2012.02.014.

Reynisdottir, M., Song, H., \& Agrusa, J. (2008). Willingness to pay entrance fees to natural attractions: An Icelandic case study. Tourism Management, 29(6), 1076-1083. Available at: https://doi.org/10.1016/j.tourman.2008.02.016.

Venkatachalam, L. (2004). The contingent valuation method: A review. Environmental Impact Assessment Review, 24(1), 89-124. Available at: 10.1016/S0 195-9255(03)00138-0.

Weaver, P. A., McCleary, K. W., Lepisto, L., \& Damonte, L. T. (1994). The relationship of destination selection attributes to psychological, behavioral and demographic variables. Journal of Hospitality and Leisure Marketing, 2(2), 93-109. Available at: 10.1300/J150v02no2_07. 